nature, scope and capabilities of these resources; to provide advice and guidance about these resources; and to study the roles and relations that exist, or should exist, among the many organizations and institutions constituting the scientific and technical information complex. The Centre is at present concentrating on developing an information processing system appropriate to its functions and on establishing the necessary preliminary liaisons. Scientific Information Notes for February-Mareh 1963 (No. 1, 5) also notes a National Science Foundation Grant to the System Development Corporation, Santa Monica, California, for research directed to the establish. ment of a computer-derived classification system for scientific documentation, and the University of Illinois has received a Foundation grant for programming, testing and evaluating an integrated, computerized data processing system for university library procedures.

\section{The Library Association}

THE annual roport of the Library Association for the year ended December 31, 1962, deals briefly with a wide variety of topics (Pp. 24. London: Library Association, 1963). A sub-committee of the National, University, College and Medical Libraries Committee set up to review the needs of libraries in the Colleges of Advanced Technology is urging that librarians of the Colleges should have the status of head of department and be members of the Academic Board. A committee has also been established to review the existing provision of specialist library sorvicos for scientists, technologists and other specialists in Government departments, public authorities, universities, colleges, research establishments and industry. Brief reports are included from representatives of the Association on joint committees and other bodios, including British Standards Institution committees and the International Federation of Library Associations.

\section{Reference Libraries and Documentation Centres in France}

THe Library Administration Department of the French Ministry of Education has published a now Directory of Reference Libraries and Documentation Establishments, under the egis of the General Delegation for Scientific and Technical Research. The Directory is published in three volumes: the first lists, in alphabetical order, reference libraries and documentation centres in Paris and the Departments of Seine and Seine-et-Oise; the second volume covers the rost of France; and the third contains maps and an alphabetical index. The subseription to this publication will cost 80 N.F. until April 30; after that it will bo 85 N.F. Further information can be obtained from the Service de vente des catalogues do la Bibliothèque nationale, 58 rue Richelieu, Paris.

\section{The Milk Marketing Board}

Marketung Boards are now an established feature of our national life, and it is important that they should report on their work from time to time. The twelfth annual report of the Production Division of the Milk Marketing Board contains a wealth of information on dairy farming in England and Wales and on what this Division does and the records it keeps (Pp. 159. Thames Ditton, Surrey: Milk Marketing Board, 1963. 7s. 6d.). Among its chief concerns are artificial insemination and progeny testing, two of the great modern aids to the officiont and economic production of good quality milk. In March 1962 the Board had 916 buls in its stud, and the ways in which these bulls are tested, selected and used are discussed. Thore is a short section also on the famous and controversial Charolais trials which bogan in 1962 and of which the results are eagerly awaited. Details are given also of the Division's veterinary service, its consulting officor service and the many surveys and investigations made by the Division. A study of the economics of milk production has shown that in 1961-62 the dairy farmer, by improved efficiency in feeding and management, achieved economios that more than offset rising costs. In spite of this overall achievement, it is found that the number of milk producers continues to fall at a rate of about 3 per cent a year. Abstracts are given of papors published by members of the staff of the Division, and in the appendixes to the report several tables and graphs are included showing the average yield of recorded herds, the number of milk producers in oach county and much information of that type. The report is well produced and profusely illustrated; it is a publication of which the Production Division can be justly proud.

\section{Radioactivity in Milk}

IN this nuclear age it is vitally important that every. thing possible should be done to minimize the amount of radioactivity to which man and animals are subject, and for this reason it is well that the Medical and Agricultural Research Councils are keeping a constant watch on the radioactivity in the human diet through the Agricultural Research Council Sub-Committee on Monitoring. A recent report contains the results of measurements of iodino-131 in milk for the past six months of 1962 and of strontium-90 for the period April-September 1962 (ARCRL 9: Interim Report on Radioactivity in Milk. Pp. vi+14. London: H.M.S.O., 1963. 2s. net). The results were obtained in a survey that included more than 200 depots which handle more than 40 per cent of Britain's total milk supply. From May until the end of August 1962 little or no iodino-131 was detected in milk. From early September onwards, however, measurable quantities were present, but the country-wido average for twolvo months did not at any time reach 20 per cent of the radiation dose which the Medical Research Council has specified as being the maximum acceptable. Levels of strontium-90 in milk incroased in all areas in the late spring and early summer of 1962, probably as the result of fall-out from nuclear weapon tests made in 1961. Again the values evon in localized areas did not exceed 20 per cent of what the Medical Research Council regards as permissible workinglevels for the assessment of dietary contamination, and for a twelve-month period the average value was less than 8 per cent of the working-level for the population as a whole. While it can be concluded from these results that the amounts of radioactivity in our diet are well below the danger point, it is only too obvious that everything possible should be done by all countries of the world to prevent the amounts in the diet from increasing.

\section{Dairy Research in Australia}

The Commonwealth Scientific and Industrial Research Organization Division of Dairy Research at Melbourne inereasos year by year in the amount of work it does and in the value of that work to the dairy industry with which it obviously enjoys a close degree of co-operation (Annual Report for year ending June 30, 1962. Pp. 18. Melbourne: Commonwealth Scientific and Industrial Research Organization, 1962). It is actively engaged in research on the role of starter bacteria in cheese-making, on the mechanization of cheese-making and on the drying of cheese. It has done much work also on the nature of the casein complex in milk, particularly on tho preparation, by a chromatographic method, of $x$-casein and the action of rennin on it. Another topic that has been intensively studied is the manufacture of butter powder, a free-flowing powdor containing 80-82 per cent of fat, which is prepared by spray-drying a dispersion of butterfat in an alkaline caseinate solution. The advantage of the product in baking is that it permits dry mixing. One of the most interesting and important items of research in the Division is its well-known work on the substances 